\title{
Investigating the Indonesian Translation of the U.S. Embassy Press Release
}

\author{
Ista Maharsi \\ Islamic University of Indonesia
}

\begin{abstract}
Translating formal text that may contain social, political, and crucial issues that involve many parties and possibly pose reactions across countries does not seem to be a simple task to complete. Due to diverse reactions of readers from different languages, a translator needs to be very careful to transfer meanings and the emotion within a text. Translation strategies, language use, types of text, genre, discourse and values are urgent issues to reconsider during the translation process. This paper investigates the translation strategies implemented in the Indonesian translation of the U.S. Embassy Press Release in response to Newsweek's Report on Alleged Desecration of the Holy Qur'an from the point of views of text, genre, and discourse as proposed by Hatim and Munday. In addition, several alternative translations are also offered to show different impacts of a translated text. Despite many translation methods that are used in doing the translation process, a text still bear its own genre, discourse and therefore stands in its own identity while at the same time the target text should keep voicing at least similar values and bring about similar impacts on readers.
\end{abstract}

Key words: text, genre, discourse, translation strategies

\section{A. Introduction}

Translation has become inseparable part of human's life since the emergence of global communication needs among countries in the world. Ranging from the down-to-earth problems as manual translation to the high level demanding translation such as International Trade Acts or any formal texts that may involve many parties, translation has provided a solution to the possible communicative breakdown. 
To understand the theory and practice of translation, it is necessary to do a comparative study on both the ST (Source Text) and TT (Target Text) so that we know how the translation process happens and how the ST undergoes many changes and adaptation to accomplish the purpose of doing the translation. Intensive as well as extensive investigation may be conducted on a particular text that can be based on a particular theory to gain a profound understanding and appreciation on why such a translation is worth doing.

This paper will discuss and analyze the ST of the U.S. Embassy Press Release in response to Newsweek's Report on Alleged Desecration of the Holy Qur'an and its translation. The arguments on the text type, register and discourse of both the ST and TT will be elaborated through comparing arid contrasting analyses. Issues on intertextuality and intentionality will also be conferred. Equally important, suggestion on probable better translation will be offered as an implication of theory in practice. It is also important to give 'a highlight touch' on the issues of genre and discourse in translation due to the extensive impact of the text of Newsweek's Report on Alleged Desecration of the Holy Qur'an. Thus, the analysis may extend to more detailed problems in order to obtain clearer explanation on the significance of the translation and its embedded values.

The selection of this theme is particularly based on my personal interest in the text. Besides, my specific perception on the political and ideological context implied in the text seems to be overwhelming in that it might have values to translation theory and practice.

\section{B. Text in Scrutiny}

Based on Reiss's text typology (Hatim and Munday, 2004), the two versions (ST written in English and TT written in Indonesian) of the U.S. Embassy Press Release in response to Newsweek Retracts Report on Alleged Desecration of the Holy Qur'an may be categorized into an informative text. The text visibly provides information, knowledge and judgment on one of Newsweek news. Thus, the form of language which is used appears to be functional languageconcise and simple.

On the other hand, the rhetorical purpose could be seen through the language employed such as the use of the words acknowledge, report, and make public in the ST and the words "berita", "yang diumumkan" and "menyatakan" in the TT. These kinds of words show the plainness and clarity that the text is aimed to inform 
something. As a consequence, the translator should be able to transfer the objectives of the text primarily through 'semantic equivalence' and considers the connotative meanings and aesthetic values as secondarily (2004: 284). Conceming with this, both ST and TT have clearly shown that giving information (or announcement) is the main agenda. Under skopos theory, this finding will accordingly influence the nature of demand on the translator as well as the method applied in translating the text (2004: 285).

It could be stated that the translation of the ST and TT is likely to be almost word-for-word translation from English into Indonesian. As compared, the ST and TT seems to bear together the same field, tenor and mode. A close inspection on register variation could be seen through the vantage use of the language (2004: 85) where the three aspects of register are observed. The Newsweek's Report on Alleged Desecration of the Holy Qur'an and its translation is, indeed, a good example of translation although a few corrections might still be possibly posed to reach better comprehensive result.

The field of the ST seems quite noticeable to define. It is all about the reaction and attitudes of the U.S Government about what Newsweek reported in one of its articles. The subject matter, therefore, could be seen as having political, social and ideological agendas between the U.S and other countries that give similar reactions to the issue. The U.S. Embassy and the person in charge of releasing this announcement may decide what kind of language that may be used to minimize bias and ambiguities in doing the translation and probable response on it.

The tenor of the text, as discussed earlier, is a formal text which shows strong relationships of power. In this case, the power of the American Government, the Power of Newsweek article and the power of the Indonesian people in responding to the press release and the consequences that it entails. In other words, . register variation has many things to do with the context of situation, the situation of being formal or informal, the situation of the institution's state of being to write the text and the situation of the text itself as having fine cohesion and coherence.

Despite its visible informative text type and its register, the ST seems to create its own genre (the context of culture) of the "conventionality governing the mode of political writing" (2004: 88). That the process of writing the text is strictly conducted under the U.S authority and supervision is a matter of convention or even legal rules. More importantly the specific purpose of writing such a text seems to overcome the overall text content. 
When talking about the bigger dimension of a text as having relations with other texts or one text is a part of other text, the notion of intertextual reference may emerge. Since the ST does not cite quotation but 'allusion' (2004: 87), the text could be categorized as having 'vertical intertextuality' with the Newsweek article on the same subject matter in that the U.S press release maintains not only a part of the article content, rather the entire "mode of expression" of the Newsweek article's tone. Therefore, it is important to note that a translator is required to understand the intertextual reference that the ST is about to refer and convey. Otherwise, inappropriate channel of communicative aspects may lose and fail to materialize.

In terms of discourse, it could be perceived that a particular attitude towards the areas of socio cultiral and political actions is obviously stated. The ST brings the issue of political discourse in which the U.S. Embassy, as the representative of the American Government, takes an action as a response to a report on alleged desecration of the Holy Qur'an published in Newsweek magazine through an announcement. Thus, not only does the ST serve as a formal announcement to communicate a subject matter that is released by an authorized institution, but in fact, it has wider dimension concerning with social, cultural and political reaction. It involves many parties that have interest and concern on the news publicized in Newsweek magazine, especially the Moslem worlds and the victims of extensive protests all around the world.

\section{ACloser Look on the U.S. Embassy Press Release}

The Indonesian version of the U.S. Embassy press release looks very well translated. Indeed, it can be understood that the text is an important document with which the credibility of the U.S. Embassy is put on stake. The mistranslation would not be tolerated due to the effects that might come out as a result of misinterpretation. Therefore, as I believe, the text is translated by a competent translator to minimize miscommunication and misinterpretation that follow. Nevertheless, none seems to be perfect in whatsoever way. A little bit adjustment might need to be posed to improve the Indonesian translation.

The translation of the first sentence in the ST into TT could be viewed as a slight slip of lexical items in which the sentence "...it cannot substantiate its report..." is translated into "... berita yang menuduh telah terjadi ..." In fact, the Indonesian translation of the sentence seems to be ambiguous and unclear. 
ST: Newsweek magazine acknowledged that it cannot substantiate its report alleging disrespect of the Holy Koran at Guantanamo Bay:

TT: Majalah Newsweek mengakui bahwa berita yang menuduh telah. terjadi penghinaan terhadap Kitab Suci Al-Quran di Guantanamo Bay tidak bisa dibuktikan kebenarannya.

AT (Alternative Translation): Majalah Newsweek mengaku tidak dapat membuktikan kebenaran berita yang dilansimya tentang penghinaan terhadap Kitab Suci Al Quran di Guantanamo Bay.

In the second sentence, the translation of "... original story..." appears to be very well conferred and proved to be effective and appropriate.

ST: ..."Based on what we know now, we are retracting our original story that an internal military investigation..."

TT: ..."Berdasarkan apa yang kami ketahui saat ini, kami menarik berita awal yang menyatakan bahwa sebuah penyelidikan internal militer..."

Comment: Had "the original story" been translated into "cerita asli" or "berita original", the sense of appropriateness and smooth. flowing sentence would have been lost.

In the third sentence, the translation of "...charges of misconduct..." would probably be better translated into "perbuatan yang menyimpang" rather than "adanya perbuatan yang salah". Likewise, the phrases "credible allegations of misconduct" and "violent protest" are quite difficult to find the appropriate Indonesian equivalences. Yet, the translator is quite successful in translating "violent protest" into "protest yang diwarnai kekerasan" which very well matches with the whole sentence.

On the other hand, "credible-allegation of misconduct" is translated into "tuduhan perbuatan yang salah yang didukung oleh bukti yang kuat". The translation seems to be a little bit awkward although it still makes sense.

ST: The U.S. Government will investigate all credible allegations of . misconduct and will take action.

TT: Pemerintah Amerika Serikat akan menyelidiki semua tuduhan . perbuatan yang salah yang didukung oleh bukti yang kuat dan akan mengambil tindakan. 
AT: Pemerintah Amerika Serikat akan menyelidiki semua tuduhan yang meyakinkan terhadap perbuatan yang menyimpang tersebut dan akan mengambil tindakan.

Another translation that sounds awkward and its alternative translation are shown below:

ST: Disrespect of the Holy Koran is not, has not been and will never be the policy of the United States.

TT: Penghinaan terhadap A-Quran bukanlah, tidak pernah, dan tidak akan pernah menjadi bagian dari kebijakan Amerika Serikat.

AT: Penghinaan terhadap Al Quran tidak, tidak pernah, dan tidak akan pernah menjadi bagian dari kebijakan Amerika Serikat.

Comments: In my opinion, the alternative translation seems to accommodate parallel structure than the TT.

In brief, the TT has shown a very good translation attempt in that it succeeds in switching to the appropriate text type, register, genre and discourse without neglecting the communicative aspects and purposes in doing the translation. The small number of 'inappropriateness' that I propose to change is other possible alternatives which might be considered as 'academic criticism.' It is not intended to judge other translation as wrong or inappropriate; rather it is an attempt to build a critical thinking on the existing translation phenomena.

\section{Possible Contributions to the Theory and Practice of Translation}

As has been discussed earlier, it is important to note that when doing a translation project, a translator needs to understand the whole context of the ST in order to grab the universal ideas that will be very essential to develop later on. Many things outside the ST such as cultural, ideological and political purposes may need to be reconsidered before translating. Therefore, applying only one or two theories of translation may not be credible enough. A translator is supposed to create his/her own theory as well as adapt and adopt theories which will work well in the text he/she is going to translate.

Hewson and Martin (1991: 184) propose applications of variational model to translations in diverse fields. Their theory suggests that "justification of any particular translation choice" is not the only thing to consider; but "the conditions 
under which the decision can be reached" that really matters. Furthermore they also argue that translation theory should be developed systematically in order to represent the language of the ST as well as that of the TT. Therefore, a proper translation is set beyond the obvious correspondence between the ST and TT which should be necessitated and the socio-cultural parameters between the ST and TT.

Now that translation problems are getting wider and more various, translators need to become smart agents in translating. The new trend of using neutral language rather than the 'male-dominant' language, for instance, seems to grow more obvious. Also, critical opinions on sensitive subjects may sometimes cause controversies such as translation themes of homosexuality and women liberation. Spivak in Venuti (2004:378) argues that the use of 'imperial language' is still worldwide in Europe and in the Third world countries. She confirms that "the act of translating into the Third World language-is often a political exercise of a different sort." Thereupon, translation theory and practice will be likely to undergo significant improvement along with the development of the social, cultural, economic, ideological and political contexts.

Practically, like the discussion on the U.S. Embassy Press Release text, some theories need to be implemented altogether and possibly involve many strategies and techniques of translation. The alternative translations that I proposed before are suggestions which are based on sense, logic and scientific blends. None of them is, without a doubt, easy to do. Yet, at least, an attempt to offer other translation might be seen as an act of 'searching for a new light' in the translation field.

Afterward, formulating a new theory seems to be even more complicated and problematical. When translating, a translator might use his/her intuition and feeling of 'appropriateness.' It does not look scientific, but I think it does exist andoften 'happens. Sense of 'appropriateness' will be susceptible to emerge as the translator's knowledge and experience are varied and thoughtful.

Awareness of the up-coming obstacles and more complicated problems faced by translation subject may encourage translators to be more sensitive and selective prior to doing the act of translating. As for being a translator may mean that he/she commits to be the agent of change in the society. It is, indeed, essential for translators to enhance his/her perspectives in order to pick the right theories and synthesize them to create better theories. Even, learning new things and submitting oneself to experience will enhance one's understanding on changing phenomena. 
Consequently, when it comes to translation, one's knowledge and experience will be put into plenty practices.

\section{E. Conclusion}

Translating is not simply decoding a language to another. However, it involves extensive activities such as transferring messages across language and culture, maintaining substantial and core ideas of the source text, and retaining as much effect and emotion of reading as the source text. Translators are required to be more vigilant and sensitive when translating published documents or political issues due to its massive impacts that may concern several countries. More importantly two interests of the countries, in this case, are put on stake.

As translation strategies develop along with genre, discourse, and many interests, a translator should be aware of the dynamics of translation knowledge and possible new theories of translation. The closer we are to the visible chance of translating, the sharper we are to perceive the existing problems and the bigger chance to create translation theories that are suitable with the local context. Nobody deserves to transfer messages and knowledge than we do. All in all, the gate of generating new theories of translation is widely open and it is worth trying.

\section{Bibliography}

Hatim, B. and Jeremy Munday. 2004. Translation: An advanced Resource Book. New York: Routledge.

Hewson, L. and Jacky Martin. 1991. Redefining Translation: The Variational Approach. London: Routledge:

U.S. Embassy. Newsweek Retracts Report on Alleged Desecration of the Holy Koran.

<www.usembassyjakarta.org/bhs/siaran-pers/newsweek_berita. html>

Venuti, L. (Ed.). 2000. The Translation Studies Reader. $2^{\text {od }}$ Edition. New York: Routledge. 